Pamiętnik Literacki 2013, 3, s. 145-151
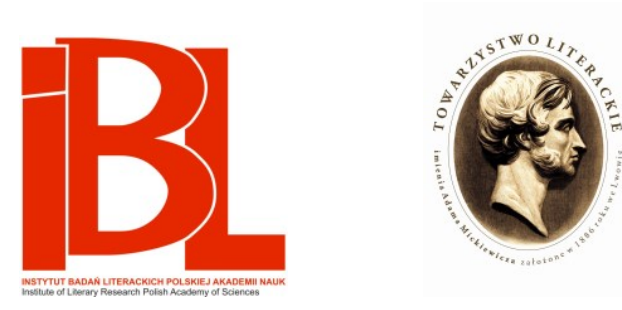

\title{
Silvae i sylwy - glosa historycznoliteracka do
} pewnego nieporozumienia

Roman Krzywy 


\section{ZAGADNIENIA JEZYKA ARTYSTYCZNEGO}

Pamiętnik Literacki CIV, 2013, z. 3 PL ISSN 0031-0514

ROMAN KRZYWY

(Uniwersytet Warszawski)

\section{SILVAE I SYLWY \\ - GLOSA HISTORYCZNOLITERACKA DO PEWNEGO NIEPOROZUMIENIA}

Pojęcie sylwy stało się nader ekspansywne w dzisiejszym literaturoznawstwie przede wszystkim za sprawą znanej książki Sylwy współczesne autorstwa Ryszarda Nycza, który posłużył się tytułową kategorią ahistorycznie, mieszając różne zakresy znaczeniowe pojęcia ${ }^{1}$. Swą atrakcyjną ${ }^{2}$ i zapewne adekwatną wobec współczesnych zjawisk literackich koncepcję autor zbudował na podstawie m.in. dociekań Stefanii Skwarczyńskiej na temat genezy i struktury manuskryptów określanych mianem ,silva rerum”. Przed laty badaczka ta postawiła tezę, iż różne zjawiska rodzajowe piśmiennictwa „bloku silva” pochodzą z jednego pnia ${ }^{3}$. Uznając pionierską wartość rozważań przeprowadzonych przez znakomitą uczoną, zastrzec od razu należy, że jej twierdzenia nie da się utrzymać w świetle obecnej wiedzy historycznoliterackiej, a nawet wymaga ono weryfikacji, zwłaszcza że utrwala je specjalistyczny słownik genologiczny ${ }^{4}$.

Nycz - za Skwarczyńską - stosuje pojęcie sylwy do wszelkich tworów piśmiennictwa mających naturę hybrydyczną, których strukturę cechuje, ujmując rzecz lakonicznie, różnorodność zarówno tematyki, jak i wykorzystanych form podawczych ${ }^{5}$. Co więcej, jak twierdzi badacz:

sylwiczne formy określają swą odrębność przez negatywne odniesienie do retorycznego modelu wytwarzania, budowy i oddziaływania wypowiedzi (a także wypracowanych w jego ramach koncepcji mimesis, autora i dzieła) - kształtując swe podstawowe wyznaczniki jako przeciwstawne ujęcia trzech zasadniczych planów retorycznego schematu: inwencji wraz z pamięcią, dyspozycji oraz elokucji ${ }^{6}$.

1 R. N y c z, Sylwy wspótczesne. Wyd. 2. Kraków 1996. Pierwodruk: Wrocław 1984.

2 Miarą owej atrakcyjności może być chociażby to, że Nyczową koncepcję zaczęli stosować także badacze kultury staropolskiej. Zob. P. B o r e k, Ukraina w staropolskich diariuszach i pamiętnikach. Bohaterowie, fortece, tradycja. Kraków 2001, s. 40 (autor tej pracy wykorzystuje ową kategorię do opisu heterogeniczności dawnego pamiętnikarstwa). Również badacze literatury najnowszej chętnie się do niej odwołują. Zob. np. J. Pł u c i e n n i k, Sylwiczność nasza powszechna i metakognicja. „Teksty Drugie” 2012, nr 6.

3 S. S k w a r c z y ń s k a, Kariera literacka form rodzajowych bloku silva. W: Wokót teatru i literatury. (Studia i szkice). Warszawa 1970.

4 Zob. A. G a w r o n, Silva rerum. Hasło w: Słownik rodzajów i gatunków literackich. Red. G. Gazda, S. Tynecka-Makowska. Kraków 2006.

5 Nycz,op. cit., s. 13-17. Zob. też S kw a rc zyńs ka, op. cit., s. 185.

6 Nyc z,op. cit., s. 15. 
Spostrzeżenia te można wszakże odnieść tylko do jednego rozumienia nazwy „sylwa”, którą za katalogami staropolskimi łączy się dziś z rozmaitymi rękopiśmiennymi miscellaneami, określanymi w inwentarzach od schyłku XVII wieku mianem ,silva rerum" ", a więc swego rodzaju rodzinnymi raptularzami prowadzonymi z potrzeby pamięci ${ }^{8}$. W tym sensie „sylwa” nie była kategorią genologiczną i rzeczywiście trudno mówić w przypadku tego typu ksiąg o nadrzędnym planie retorycznym.

Jednakże w rozumieniu taksonomicznym „sylwy” to formy jak najbardziej wywiedzione z praktyki oratorskiej, znajdujące zatem odzwierciedlenie w rozważaniach teoretyków wymowy i poezji, a także podporządkowane prawidłom sztuki retorycznej w każdym z jej zakresów. W traktacie Macieja Kazimierza Sarbiewskiego O poezji doskonatej przeczytać można np.:

Kwintylian uczy, że sylwy są to małe poematy napisane w nagłym przypływie natchnienia (to samo podaje Stacjusz we wstępie do zbioru Silvae), które charakteryzują obfitość i mnogość poruszanych tematów. Każda sylwa zatem jest jak gdyby utworem o całym gąszczu tematów, mało różnym od dzieł krasomówczych, natomiast zasadniczo różniącym się od poezji epickiej i bohaterskiej, podobnie jak od komicznej i tragicznej, i wszystkich innych, [...] które odmiennie, niż to bywa w sylwach, przestrzegają jedności fabuły i zawsze w pewnym stopniu odznaczają się ogólnością, choćby nieraz były bardzo krótkie i nie przekraczały rozmiarów sylwy ${ }^{9}$.

Z tego ogólnego wprowadzenia da się wydobyć kilka ważnych cech sylw. Po pierwsze, ich tematyka może być bardzo różnorodna, ale nie oznacza to zamierzonej varietas $\mathrm{w}$ obrębie jednego dzieła, lecz po prostu brak treściowych ograniczeń utworów sylwicznych. Po wtóre, są to poematy wywiedzione z retoryki, a dokładniej rzecz ujmując, przede wszystkim z retorycznego genus demonstrativum, w mniejszym zaś stopniu z genus deliberativum - co wynika z dalszych rozważań Sarbiewskiego, ale i jest wskazane pośrednio przez przywołanie przezeń zbioru Stacjusza ${ }^{10}$. Po trzecie, sylwy nie mają charakteru naśladowczego w tym sensie, że ich celem nie jest kreowanie fabuły, która odpowiadałaby zasadzie ogólności poetyckiej, szeroko oma-

7 Jak zauważył badacz sylw XVIII-wiecznych: „Samo określenie »silva rerum« pojawiło się później w stosunku do wymienionych tytułów [tj. miscellanea, nihil et omnia, penum synopticum, varia, vorago rerum, otia publica, otia domestica, wirydarz, korab Noego - R. K.], i to raczej przy okazji sporządzania rejestrów czy inwentarzy, jeśli, oczywiście, spisujący je urzędnicy uznali rękopis za rzecz wartościową" (S. R o s z a k, Archiwa sarmackiej pamięci. Funkcje i znaczenie rękopiśmiennych ksiag silva rerum w kulturze Rzeczypospolitej XVIII wieku. Toruń 2004, s. 49). Pierwsze użycia nazwy „silva rerum” wobec kodeksów rękopiśmiennych odnotowane przez Roszaka pochodzą z końca w. XVII i z XVIII. Oznacza to, że dla prowadzących księgi domowe nie wskazywała ona typu piśmienniczego, którego podstawowym wyznacznikiem byłaby określona struktura rodzajowa.

${ }^{8}$ Zob. S k w a r c z y ń s k a, op. cit., s. 184. To typowe dla kultury szlacheckiej zjawisko omawia M. Z a c h a r a: Sylwy-dokument szlacheckiej kultury umystowej w XVII wieku. W zb.: Z dziejów życia literackiego w Polsce XVI i XVII wieku. Red. H. Dziechcińska. Wrocław 1980; Twórcaodbiorca sylw szlacheckich w XVII wieku. W zb.: Publiczność literacka i teatralna w dawnej Polsce. Red. H. Dziechcińska. Warszawa-Lódź 1985. Zob. też J. P a r t y k a, Rękopisy dworu szlacheckiego doby staropolskiej. Warszawa 1995. - R o s z a k, op. cit. - M. B a rł o w s k a, Swada i milczenie. Zbiory oratorskie XVII-XVIII wieku - prolegomena filologiczne. Katowice 2010, s. 112-155.

9 M. K. S a rbi e w s ki, O poezji doskonatej, czyli Wergiliusz i Homer. (De perfecta poesi, sive Vergilius et Homerus). Przeł. M. P 1 e z i a. Oprac. S. S k i m in a. Wrocław 1954, s. 236. BPP, B 4.

${ }^{10} \mathrm{O}$ specyfice obu rodzajów zob. J. Z i o m e k, Retoryka opisowa. Wyd. 2, popr. Wrocław 2000, s. 61-64. 
wianej przez Sarbiewskiego we wcześniejszych księgach traktatu. Po czwarte, sylwy stanowią utwory niedużych rozmiarów (co, oczywiście, względne, lecz idzie o stosunek do „standardowej” długości eposu czy dzieł dramatycznych) ${ }^{11}$. Po piąte w końcu, sylwy wyróżnia okolicznościowość, powstają one bowiem jako doraźna reakcja na bieżące wydarzenia, stąd też nie muszą odznaczać się starannością opracowania, lecz mogą sprawiać wrażenie napisanych ,w nagłym przypływie natchnienia" (rzecz jasna, niekoniecznie musi to wskazywać na niewykończenie utworuchoćby i sami autorzy sugerowali to we wstępach, kierując się poczuciem rzekomej skromności - ale na, typowy dla improwizowanych w pośpiechu pochwał, styl podniosły).

Zapowiadając dalej scharakteryzowanie poszczególnych odmian sylw, stwierdza „chrześcijański Horacy”, że mają one za przedmiot „ludzi żywych lub niedawno zmarłych” i towarzyszą różnym okolicznościom życia ludzkiego, ,któremu [...] służyć mają nie tyle dla pożytku - jak poezja epicka i inne omówione - ile dla rozrywki" "12. Ostatnia konstatacja nie jest do końca prawdziwa, gdyż z genus demonstrativum w czasach preceptora poetyki wiązano cele wychowawcze, lecz pominął on ten fakt milczeniem, by w wykładzie dobitniej zarysowała się opozycja form ,poezji doskonałej” i niemimetycznej ${ }^{13}$. Wśród utworów sylwicznych wymienił Sarbiewski: genetliakon, epitalamium, epicedium, wiersze gratulacyjne, dziękczynne, powitalne, pożegnalne, pochwały zwycięzców, różnego rodzaju panegiryki, a w ich pobliżu sytuował hymny na cześć bogów, idylle i bajki ${ }^{14}$. Po szczegółowe wskazówki, jak należy je pisać, teoretyk odsyłał odbiorców do księgi III Poetyki Juliusza Cezara Scaligera, nadmieniając raz jeszcze:

wszystkie sylwy należą raczej do dziedziny krasomówstwa niż poezji, bo można w nich wyczerpać wszystkie motywy znamienne dla wymowy popisowej i doradczej jeszcze swobodniej niż w utworze prozaicznym, np. w pochwałach urodzinowych albo w pieśni pogrzebowej ${ }^{15}$.

11 Także F. R o b o r te 11 o (Wyjaśnienie tego wszystkiego, co odnosi się do metody i kunsztu pisania epigramatów. Przeł. J. M a ń k o w s k i. W zb.: Poetyka okresu renesansu. Antologia. Wybór, wstęp, oprac. E. S a rn ow ska-Te merius z. Przypisy J. Mańkowski, E. S a rnow ska- Te m e ri us z. Wrocław 1982, s. 95. BN II 205) charakteryzował sylwy jako gatunek utworu wierszowanego mniejszych rozmiarów (obok wymieniał satyrę, list poetycki i epigramat), przeciwstawiając je tragedii, komedii i eposowi.

12 S arbiew s ki, op. cit., s. 246.

13 Już P linius z Młods z y określił cel swego Panegiryku na cześć Trajana, utworu niezwykle popularnego w dawnych wiekach, jako parenetyczny, a wcześniej potencję wychowawczą pochwał ludzi dostrzegał przecież Plat on w Protagorasie i w Państwie. Zob. R. Krzyw y, Aspekt panegiryczny twórczości Samuela Twardowskiego. W zb.: Wielkopolski Maro. Samuel ze Skrzypny Twardowski i jego dzieło w wielkiej i małej ojczyźnie. Red. K. Meller, J. Kowalski. Poznań 2002, s. 103.

${ }^{14} \mathrm{~S}$ a r b i e w s k i, op. cit., s. 248, zob. też s. 246-248. Inny teoretyk z tego czasu pisał o sylwach: „Są one [...] również tym, co niesie już sama ich nazwa wzięta z porównania z lasem, w którym znaleźć można drzewa różnych rodzajów i odmian, a zatem obejmują one wszelakie religijne i świeckie wiersze, a wśród nich pieśni o weselach i narodzinach, powinszowania szczęśliwie przebytej choroby, pieśni o podróżach albo o powrocie z nich i temu podobne" (M. O p i t z, Ksiegga o poezji niemieckiej. Przeł. E. F e li k s i a k. W: Poetyka okresu renesansu, s. 546-547). Nb. fakt, że do ksiąg rękopiśmiennych typu silva rerum włączano wiersze okolicznościowe (ale także - i to o wiele częściej - różnego rodzaju oracje, rejestry, sprawozdania itp.), nie powinien być uznawany za przesłankę do twierdzeń na temat pokrewieństwa obu rodzajów „sylwicznego” piśmiennictwa, jak zdaje się sugerować R os zak (op. cit., s. 48-49).

${ }^{15} \mathrm{~S}$ a r b i e w s k i, op. cit., s. 248. W genologicznej części księgi III swego kompendium scha- 
Motywy, o jakich mowa w cytowanym przekładzie, to toposy (loci), którymi poeta - jak twierdzi Sarbiewski - może posługiwać się swobodniej niż orator (co oznacza de facto szerszy zakres doboru punktów treściowych, więc mniejsze rygory w kształtowaniu inventio). Nieco dalej autor traktatu zwrócił także uwagę na to, że w sylwach o wiele chętniej niż w mowach sięgają twórcy po efektowne figury myśli, jak hypotypozy, plazmaty i prozopopeje, co zapewne sugerować miało większą obrazowość sylw niż odpowiadających im gatunków oracji ${ }^{16}$.

Oba znaczenia pojęcia sylwa - genologiczne i raptularzowe - łączy, oczywiście, źródłosłów oraz doraźny charakter utworu poetyckiego czy zapisu w domowej księdze. Sarbiewski powoływał się na opinię Kwintyliana o sylwach. Rzymski retor terminem owym określił rodzaj brulionu, w którym mówcy notują „bez namysłu wszystko, co tylko podyktuje [...] świeży zapał i rozmach" ${ }^{17}$. Ganił on takich oratorów, gdyż, jak uważał, nawet po wygładzeniu słów, rytmu i ponownym zredagowaniu treści ,zebranej tak na oślep [...] pozostaje nadal pierwotna jej płytkość" ${ }^{18}$. Te właśnie robocze notaty przeznaczone do dalszego opracowania nazywano w jego czasach ,gęstwiną” (silvae). Do tego rozumienia słowa odwołał się Stacjusz - twórca niewiele młodszy od Kwintyliana - który w dedykacji księgi I swego zbioru Silvae pisał nie bez pewnej kokieterii:

Długo i mocno zastanawiałem się [...], czy zebrać te utwory, które mi się napisały w doraźnym zapale i pośpiechu. [...] Żaden z nich przecież nie powstawał dłużej niż dwa dni, a niektóre wyrosły nawet $\mathrm{w}$ jednym dniu. I lękam się, by prawdziwości tego nie potwierdzały one same o sobie ${ }^{19}$.

rakteryzował Scaliger m.in. utwory okolicznościowe, opatrując je nagłówkiem Silvae. Jak zapowiedział, są to formy wyróżnione ze względu na treść (idea). Jego praecepta omówił B. N a d o ls k i (Scaliger o rodzajach renesansowej poezji dworskiej. „Acta Universitatis Nicolai Copernici” 1979, z. 95). Zob. też J. N i e d ź w i e d ź, Nieśmiertelne teatra sławy. Teoria i praktyka twórczości panegirycznej na Litwie w XVII-XVIII w. Kraków 2003, s. 63-64, 70-72, 174-175.

16 Zob. T. M i c hałow s k a, Staropolska teoria genologiczna. Wrocław 1974, s. 130-131. - E. K o tar s k i, Poezja okolicznościowa i tradycja retoryczna. W zb.: Sarmackie theatrum. T. 2: Idee i rzeczywistość. Red. R. Ocieczek, przy współudz. M. Barłowskiej. Katowice 2001, s. 101-103. - N i e dź wi e dź, op. cit., s. 174-175.

${ }^{17}$ Marek Fabiusz Kwintylian, Ksztatcenie mówcy. Księgi I, II $i$ X. Przeł., oprac. M. B r o ż e k. Wrocław 1951, s. 314 (X 3, 17). BN II 62. Omawiając lapidarnie pochodzenie kategorii rodzajowej silvae, także S c a li g e r odsyłał w swoim traktacie (III 100) właśnie do Kwintyliana, ale odnosił ją do utworów poetyckich. Jak można mniemać, ogólne sformułowania renesansowego teoretyka skłoniły S k w a r c z y ń s k ą (op. cit., s. 187-188) do nazbyt pochopnego utożsamienia różnych pojęć. Scaliger nie był pierwszym humanistą zastanawiającym się nad znaczeniem interesującego nas terminu. Już w XV stuleciu, pisząc o sylwach, A. P o li zi a n o uznawał je za genus scriptionis, dla którego najważniejsze były: pośpiech twórczy, okolicznościowość i różnorodna zawartość. Dla Scaligera, nadmienić warto, specyficzną cechę tych tekstów stanowiła dominanta panegiryczna. Zob. H.-J. v a n D a m, Wandering Woods Again: From Poliziano to Grotius. W zb.: The Poetry of Statius. Ed. J. J. L. S m o 1 e n a a r s, H.-J. v a n D a m, R. R. N a u ta. Leiden-Boston 2008, s. 46, 50.

${ }^{18} \mathrm{~K}$ w i n t y l i a n, loc. cit. Retor zalecał w związku z tym, by od razu z odpowiednim namysłem pracować nad mową.

19 S t a c j u s z, Sylwy. Przeł., komentarz M. B r o ż e k. Wrocław 1996, s. 3. Wysunięcie przez rzymskiego poetę improwizatorskiego charakteru dzieła na pierwszy plan za najbardziej prawdopodobne uznaje H. S z e le st (,, Sylwy” Stacjusza. Wrocław 1971, s. 12), nadmieniając także, iż A u 1 u s Gelli u s z we wstępie do Nocy attyckich określał owym słowem zbiór utworów nie powiązanych ze sobą tematem (podobnie $\mathrm{S}$ w e to n i u s z w dziele De grammaticis). To znaczenie z pewnością też współtworzyło treść terminu ,silva”, aczkolwiek Stacjusz nie odwołuje się do niego. 
Rzekomo pośpieszna praca nad dziełem, która pozwoliła je określić mianem „sylw” - utworu niedoskonałego, skłoniła półtora tysiąca lat później Andrzeja Frycza Modrzewskiego w przedmowie do tomu rozpraw na tematy religijne do interesujących wyznań uzasadniających zastosowanie badanego terminu w tytule tego zbioru:

Niech nikt nie myśli, że Frycza [...] nie było stać na wydanie czegoś lepszego niż to, co stworzyli dawniejsi pisarze [...]. Owszem, niech każdy raczej nabierze przeświadczenia, że ani słowa nie powiedziałem od siebie, lecz zebrałem w jedną całość wszystko, czego od innych się dowiedziałem, czyniąc to z niejakim staraniem oraz poddając pewnemu osądowi, o ile oczywiście było to możliwe przy moich niewielkich zdolnościach i miernym wykształceniu. Wielu jednakże pism łączących się z tematem nie oglądałem ani nie miałem pod ręką. $Z$ tych znowu, które miałem w ręku, może nie wszystkie zbadałem dość wnikliwie. Najczęściej czytałem i pisałem jakby w przelocie. Nie ulega też wątpliwości, że w naporze myśli i w nawale zajęć [...] tok moich prac i rozważań musiał ulegać zamieszaniu i zakłóceniu.

Sam przeto widzę, że w dziele niniejszym jest mnóstwo miejsc takich, które wymagają wygładzenia i uzupełnienia. [...]

W świat tedy puszczam księgi chropawe, niedoskonałe, napisane w pośpiechu, dlatego też nadaję im miano $S y l w^{20}$.

Frycz zatytułował tom rozpraw Sylwami w znaczeniu kwintylianowym (rzecz pisana $\mathrm{w}$ pośpiechu, niedoskonała), mimo że da się wskazać w przytoczonych słowach sformułowania (,niewielkie zdolności”, ,mierne wykształcenie”) typowe dla topiki konwencjonalnej skromności, której dopatrywać się można również w wyznaniu Stacjusza z cytowanego wcześniej exordium, jakkolwiek gatunkowo nic obu dzieł nie łączy ${ }^{21}$. Zauważmy też, że żaden z tych dwóch autorów nie podnosił kwestii różnorodności tematycznej czy formalnej jako istotnej cechy własnej pracy.

Do nadania terminowi ,sylwa” sensu genologicznego niewątpliwie przyczynił się zbiór Stacjusza. W 5 księgach pomieścił on rozmaite odmiany utworów okolicznościowych (genetliakon, soterion, epitalamium, epicedium, konsolacja, propemptikon itp.), w których rozbudowany jest zwykle pierwiastek enkomiastyczny. Jako pierwszy poświęcił Stacjusz dłuższe wiersze pochwalne zdarzeniom z życia codziennego rodziny i przyjaciół nie mającym żadnego znaczenia ogólnego (wcześniej tematyka owa była domeną przede wszystkim epigramatu), dając tym samym wzorce poezji sylwicznej (nazwanej później okolicznościową, a ostatnio - jak słyszymy - okazjonalną) $)^{22}$. Dzieło Stacjusza odkrył Gianfrancesco Poggio Bracciolini w 1417 roku w Sankt Gallen (w średniowieczu znano i podziwiano jedynie

O starożytnej semantyce określenia i o kwestii improwizatorskiego charakteru poematów Stacjusza pisali J. S t y k a (Sydoniusz Apollinaris i kultura literacka w Galii Vwieku. Kraków 2008, s. 77-81) i S. Ś n i e ż e w s k i (Stowo i obraz. Studia historycznoliterackie nad, ,Sylwami” Stacjusza. Kraków 2010, s. 23-28).

${ }^{20}$ A. Frycz Modrzewski, Sylwy. Przeł. L. Joachimowicz. Wstęp Ł. Kurdyb a c h a. Red. nauk. przekładu, komentarz K. G ó r s ki. Warszawa 1959, s. 41-42.

${ }^{21}$ M. K o r o 1 k o w pracy Andrzej Frycz Modrzewski. Humanista, pisarz (Warszawa 1978) uważał, że Kwintylianowy zakres pojęcia (,,pierwszy, improwizowany szkic pisemny mowy”, s. 152) doprowadził do wykształcenia się formy piśmienniczej, którą upowszechniono i wzbogacono po wynalezieniu druku. Sylwy retoryczne (,nazywane inaczej miscellanea, lucubratio, encheiridion itp.”, s. 152) jako materiały pomocnicze dla mówców miały, zdaniem badacza, przyczynić się do powstania gatunku eseju, za którego przykład Korolko uznał dzieło Modrzewskiego. Kwestia eseistyczności tych utworów z pewnością jednak wymaga jeszcze gruntownego namysłu.

22 Zob. S zele s t, op. cit., s. 111-112. 
Stacjuszową Tebaidę) $)^{23}$. Niezwykła popularność Sylw nastąpiła nie od razu po ich odkryciu (do zapoznania się z nimi zniechęcała trudność tekstu i stopień zepsucia manuskryptu), lecz dopiero po ogłoszeniu drukiem w 1472 roku. Publikacja wzbudziła olbrzymie zainteresowanie wśród humanistycznej republiki uczonych, którzy skwapliwie przystąpili do komentowania (erudycyjne uwagi na temat zbioru poczynili Domizio Calderini, Angelo Poliziano; zwłaszcza sława tego drugiego jako wybitnego znawcy kultury starożytnej przysłużyła się recepcji Sylw Stacjusza w czasach renesansu i baroku) oraz do naśladowania utworów zawartych w tomie ${ }^{24}$. Wedle Scaligera - Stacjusz jako autor Sylw stał na tym samym poziomie co Wergiliusz ${ }^{25}$, a przyrównanie takie potraktować należy jako najwyższy komplement w epoce, kiedy Eneida uznawana była za arcydzieło, granicę talentu literackiego nie do przekroczenia. Silvarum libri pozostawili np. Angelo Poliziano, George Buchanan, Nikolaus von Reusner, Martin Opitz czy Hugo Grotius, by wymienić tylko niektórych ${ }^{26}$. Są to pisarze absorbujący dziś uwagę głównie badaczy twórczości nowołacińskiej, niemniej w swoich czasach - gdy łacina pozostawała wciąż znaczącym medium poetyckim - należeli do autorów chętnie czytywanych, postrzeganych nawet jako wybitni.

Europejska popularność poezji sylwicznej nie przeszła bez echa także w Polsce. W roku 1514 Jan Dantyszek napisał wiersz Sylvula de victoria inclyti Sigismundi, regis Poloniae, contra Moschos, opiewający zwycięstwo polskiego oręża pod Orszą. Gatunkowo jest to epinikion - pojawiające się w tytule słowo „sylvula" oznacza 'małą sylwę', więc nieduży utwór okolicznościowy (liczący 108 wersów), ułożony - jak autor podkreśla - w pośpiechu na wieść o tryumfie ${ }^{27}$. Pod koniec następnej dekady poeta ogłosił wiersz De nostrorum temporum calamitatibus Silva, będący po części pobudką skierowaną do władców chrześcijańskich, z cesarzem i papieżem na czele, wzywającą wobec upadku Budy i oblężenia Wiednia do nowej krucjaty przeciw Turkom, a częściowo stanowiący też usprawiedliwienie ugodowej polityki króla Zygmunta Starego wobec Porty Otomańskiej ${ }^{28}$. Tekst ma cele publicystyczne i świadczy o poszerzeniu zakresu tematycznego sylw o treści i argumentację typową dla poezji zaangażowanej politycznie (korzystał więc autor przede wszystkim ze strategii charakterystycznej dla genus deliberativum). Wyraźny patronat Stacjusza daje się natomiast zauważyć w przypadku 3 ksiąg łacińskich Sylw Andrzeja Trzecieskiego, publikowanych w latach $1568-1575$. Zbiory te zawierają głównie utwory adresowane do współczesnych mu władców, magnatów, przyjaciół, innych pisarzy (w jednej z ksiąg zamieszczona jest np. ciekawa sylwa skierowana do Jana Kochanowskiego) czy mecenasów, którym dedykował Trzecieski nieduże poematy o bardzo rozmaitym charakterze. Znaleźć tu można różnego rodzaju życzenia,

${ }^{23}$ Zob. E. R. C u r ti u s, Literatura europejska i łacińskie średniowiecze. Przeł., oprac. A. B oro w s k i. Wyd. 2. Kraków 1997, s. 24. - M. B r o ż e k, Geneza formy i treści w ,Sylwach” Stacjusza. „Meander” 1966, nr 11/12, s. 453.

${ }_{24}$ Zob. S. Z a b ł o c k i, Poetyka renesansowego epicedium. W: Od starożytności do neohellenizmu. Studia i szkice. Red. P. Urbański, T. Sapota. Katowice 2008, s. 165-166.

${ }_{25}$ Zob. ibidem, s. 168-169.

${ }^{26}$ Modę tę omawia v a n D a m (op. cit., s. 49-64), łącząc ją m.in. z popularnością utworów i komentarzy Poliziana oraz wydzieleniem przez Scaligera sylw jako podrodzaju poetyckiego.

27 Zob. Z. N o w a k, Jan Dantyszek. Portret renesansowego humanisty. Wrocław 1982, s. 234.

${ }^{28}$ Zob. S. S k i m i n a, Twórczość poetycka Jana Dantyszka. Kraków 1948, s. 54-56. 
gratulatoria, powitania, pożegnania, epitalamia, pobudki, trenodię, wiersze na herby, zalecenia dzieł innych autorów, napomnienia oszczercy, ale również polemiki antyariańskie i utwory religijne (np. Hymn na święto Objawienia Pańskiego). Jakkolwiek więc dominują u Trzecieskiego teksty o charakterze enkomiastycznym, nie stronił też autor od publicystyki politycznej i wyznaniowej oraz wierszy religijnych. Potwierdza to otwartość sylw na tematykę wykraczającą poza tradycyjny zakres panegiryków ${ }^{29}$.

Jak wynika z obserwacji poczynionych w niniejszym artykule, sylwy szlacheckie i sylwy w rozumieniu genologicznym, obejmującym spowinowacone retoryczną genezą gatunki poetyckie, które nawiązywały w mniej lub bardziej wierny sposób do zbioru Stacjusza, to zjawiska nietożsame. Poza nazwą niewiele je łączy. Status twórczości sylwicznej był od czasów renesansu precyzowany przez nauczycieli poetyki i samych pisarzy - dla nich rzymski precedens okazał się z jakichś powodów atrakcyjny oraz godny naśladowania. Lecz ten nurt twórczy nie korespondował ze swobodą i rozmaitością tematyczną notat prowadzonych przez szlachtę, swobodą, która pozwalałaby na wypromowanie koncepcji uznającej istnienie od czasów antycznych trwałej inklinacji w dążeniu do fragmentaryzmu, eseistyczności czy budowy niezgodnej z zasadami retoryki (choć, oczywiście, takie utwory powstawały od wieków i z zastanawiającym upodobaniem są pisywane obecnie). Zbyt pochopne kojarzenie odrębnych zjawisk należących do literatury dawnej i konstruowanie spójnej koncepcji wynikającej z uwzględnienia ich cech swoistych, jakkolwiek prowadzić może do całkiem interesujących, a nawet prawdziwych stwierdzeń na temat kultury XX-wiecznej i najnowszej, zdaje się jednak zanadto fałszować naturę tych zjawisk.

\section{A b stract}

ROMAN KRZYWY

(University of Warsaw)

\section{SILVAE AND SILVAS \\ - A LITERARY HISTORY GLOSS TO THE MISUNDERSTANDING}

The author in his article proves that the presently immensely popular in Polish literary studies category of the silva is defined as based on contaminating its two different scopes of meaning, namely one rooted in literary genetics, referring to the tradition of popular from the Renaissance Statius' collection with occasional texts, and the other, utilitarian, connected with the practice of the nobility's running private home books with notes of various nature. Considering the statements by writers, rhetoricians and poetry theoreticians, and collections of poetry with examples of silvas, the author attempts to clear up that terminological mess.

${ }^{29} \mathrm{Na}$ temat treści zbiorów sylwicznych poety zob. J. K ró k o w s k i, Andrzej Trzecieski. Poeta-humanista i działacz reformacyjny. Warszawa 1954, s. 91-102, 112-117. 